\title{
Erratum to: Population genetic analysis of Euro-Arctic polar cod Boreogadus saida suggests fjord and oceanic structuring
}

Matias L. Madsen ${ }^{1} \cdot$ R. John Nelson ${ }^{2} \cdot$ Svein-Erik Fevolden $^{1} \cdot$ Jørgen S. Christiansen $^{1}$ • Kim Prabel ${ }^{1}$

Published online: 22 December 2015

(C) Springer-Verlag Berlin Heidelberg 2015

\section{Erratum to: Polar Biol}

\section{DOI 10.1007/s00300-015-1812-y}

The second author's name should be R. John Nelson and not John R. Nelson.

The online version of the original article can be found under doi:10.1007/s00300-015-1812-y.

Matias L. Madsen

matias.madsen@gmail.com

1 Faculty of Biosciences, Fisheries and Economics, UiT The Arctic University of Norway, 9037 Troms $\varnothing$, Norway

2 Department of Biology, University of Victoria, Victoria, BC V8W 3N5, Canada 